NBS PUBLICATIONS

NB NATL INST OF STANDARDS \& TECH R.I.C.

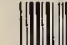

\title{
Relative Propensity of Selected Commercial Cigarettes to Ignite Soft Furnishings Mockups
}

John F. Krasny

Richard G. Gann

U.S. DEPARTMENT OF COMMERCE

National Bureau of Standards

Center for Fire Research

Gaithersburg, MD 20899

June 1986

$-A C \quad$ isored by

$100 \quad$. Consumer Product Safety Commission

.1156 shington, DC

$86-3421$

1986

c. 2 

U.S. DEPARTMENT OF COMMERCE

National Bureau of Standards

Center for Fire Research

Gaithersburg, MD 20899

June 1986

Sponsored by

U.S. Consumer Product Safety Commission

Washington, DC

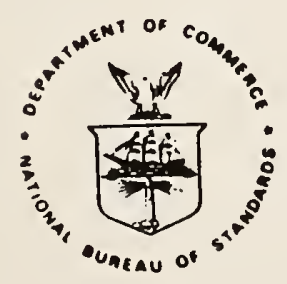

U.S. DEPARTMENT OF COMMERCE, Malcolm Baldrige, Secretary NATIONAL BUREAU OF STANDARDS. Ernest Ambler, Director 



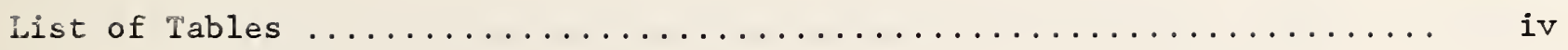

List of Figures $\ldots \ldots \ldots \ldots \ldots \ldots \ldots \ldots \ldots \ldots \ldots \ldots \ldots \ldots \ldots \ldots$

Abstract $\ldots \ldots \ldots \ldots \ldots \ldots \ldots \ldots \ldots \ldots \ldots \ldots \ldots \ldots \ldots \ldots \ldots \ldots \ldots$

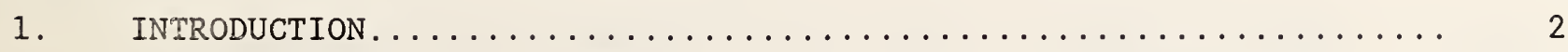

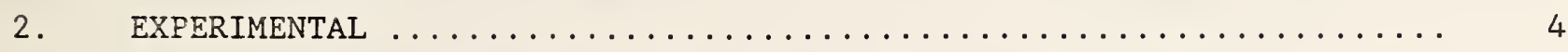

2.1 Test Protocol Development..................... 4

2.2 Substrate Material Selection....................... 6

2.3 Cigarette Packing Selection..................... 10

3. RESULTS AND DISCUSSION......................... 10

3.1 Number of Ignitions......................... 10

3.2 Mass Loss Data Obtained During Tests................. 15

3.2.1 Mass Loss Data on Igniting Substrates.............. 15

3.2.2 Mass Loss on Self-Extinguishing Substrates.......... 16

3.3 Effect of Ambient Humidity.................... 17

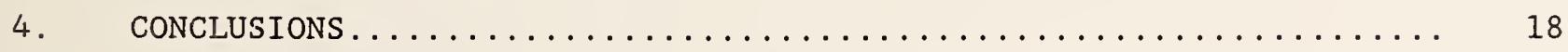

5. ACKNOWLEDGMENTS ............................ 19

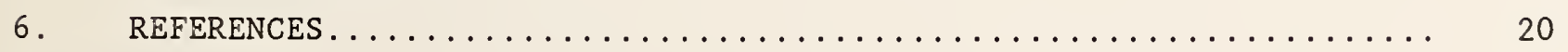

APPENDIX A

APPENDIX B

APPENDIX C

APPENDIX D 


\section{LIST OF TABLES}

$\underline{\text { Page }}$

Table 1. Number of Ignitions By Substrate and Cigarette

Packing.

Table 2. Number of Cigarette Ignitions by Substrate Factor (California

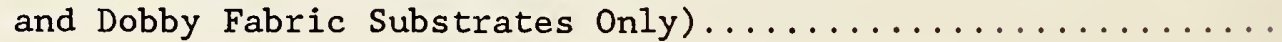

Table 3. Number of Cigarette Ignitions by Substrate Factor (Including Tulip Fabric)

Table 4. Time to 2, 4, and 5 g Mass Loss of Igniting Substrates........ 25

Table 5. Mass Loss of PU/Fabric Substrates, No Ignitions............ 26

Table 6. Comparison of Typical Individual Ignition Results at Greatly

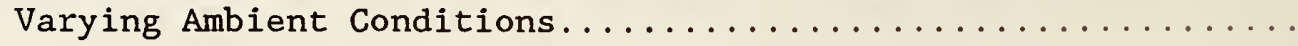




\section{LIST OF FIGURES}

$\underline{\text { Page }}$

Figure 1. Mass Loss/Time Relationship for an Igniting and a

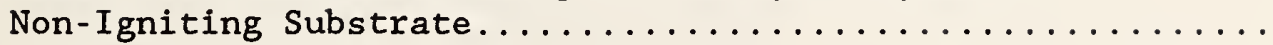



RELATIVE PROPENSITY OF SELECTED COMMERCIAL CIGARETTES TO

IGNITE SOFT FURNISHINGS MOCKUPS

John F. Krasny

Richard G. Gann

\begin{abstract}
This report covers the first project performed under the Cigarette Safety Act of 1984, the determination of whether and to what extent commercial cigarettes have differing propensities to ignite upholstered furniture substrates. For this purpose, a test protocol was developed under which 12 types of commercial cigarettes were placed on 18 substrates varying in fabric, padding, and configuration. It was found that there are statistically significant differences in ignition propensity among the cigarettes (at the one percent or better confidence level) on three substrates. No significant differences were found on the other 15 substrates. No one of the packings consistently showed low ignition propensity on all three substrates. The mass loss rate of both the cigarette and substrate during the tests was recorded and did not appear to be a reliable predictor of ignition propensity.
\end{abstract}

Key words: Cigarettes; fabrics; furniture; furniture padding; ignition source; smoldering ignition; upholstered furniture. 


\section{INTRODUCTION}

The Cigarette Safety Act of 1984 (Appendix A) was passed as a rational approach to reducing the losses due to fires caused by cigarettes inadvertently dropped on upholstered furniture or mattresses (soft furnishings). The 1983 estimates for smoking-caused fire losses in the United States were [1,2]:

\begin{tabular}{|c|c|c|c|}
\hline & Number & 8 of Residential & 8 of Total \\
\hline Fires & 49,000 & 8 & 2 \\
\hline $\begin{array}{l}\text { Deaths } \\
\text { Civilian \& } \\
\text { firefighter }\end{array}$ & 1,580 & 33 & 27 \\
\hline $\begin{array}{l}\text { injuries } \\
\text { Property loss }\end{array}$ & 6,810 & 32 & 22 \\
\hline$\$$ millions & 290 & 5 & 4 \\
\hline
\end{tabular}

While the number of cigarette-initiated fires and the property losses associated with them are only a small percentage of the total numbers, they account for a quarter of the deaths and injuries. The available statistics do not include the casualties and losses due to cigarette initiated forest and grass fires.

Some years ago it was found that several commercial cigarette packings ${ }^{1}$ had a lower propensity to ignite soft furnishings than certain other packings $[3,4,5]$. Similar results were found in later studies $[6,7]$. Based in part on the earlier studies, bills were introduced in the U.S. Congress and several state legislatures as early as 1979 which required that cigarettes be made less

1 A cigarette packing is defined as a commercial cigarette, described by 1 ts name, sometimes its diameter, its length, whether menthol or non-menthol. whether filter or non-filter, and by its package type (e.g., soft pack). 
ignition prone within a certain period. This requirement gave little consideration to technical practicability, cost, or means of defining such lower propensity to ignite. A revised bill, the Cigarette Safety Act of 1984, became law in October 1984 (Appendix A). It requires a study of the technical and commercial feasibility, economic impact, and other consequences of developing cigarettes which will have a minimum propensity to ignite soft furnishings. This work is guided by a Technical Study Group constituted under the this Act. As the first project, the Technical Study Group asked the Center for Fire Research (CFR) of the National Bureau of Standards (NBS) to determine differences in the propensity to ignite soft furnishings of selected, presentday, commercial cigarette packings.

The present report describes experiments to determine to what extent differences exist in the propensity of 12 commercial cigarette packings to ignite soft furnishings. More specifically, the work involved the following:

- modification of the test methods previously used for evaluating the cigarette ignition resistance (CIR) of upholstered furniture and mattresses for the present purpose;

- specification and procurement of equipment;

- selection, procurement and testing of fabrics and padding materials which would illustrate any differences in cigarette ignition propensity; 
- determination of the alkali and alkaline earth metal content of substrate materials by the Consumer Product Safety Commission's (CPSC) analytical laboratory and a commercial laboratory;

- choice and procurement of cigarette packings which held large market shares or, on the basis of earlier work $[3,4,6,7]$ might be expected to show differences in ignition propensity;

- carrying out of the 864 tests in the testing matrix (four replicates of twelve cigarette packings on 18 substrates $^{2}$ each); and

- analysis of the combined results.

\section{EXPERIMENTAL}

\subsection{Test Protocol Development}

In order to develop a test method and protocol for the purpose of this work, the Technical Study Group formed a test planning team of experts. This team consisted of:

2 The term "substrate" is used to describe one combination of a specific fabric, padding, in either the flat or crevice arrangement, with or without a cover sheet; e.g., the flat area of a piece of polyurethane foam (PU) covered with the California Standard fabric, with the cigarette covered by sheeting. The flat area with the same materials but with the cigarette not covered would be a different substrate. 
H. Cohen, Consumer Product Safety Commission

G. Damant, Chief, Bureau of Home Furnishings, State of California

A. Klancnik, Sealy Inc.

J. Krasny, Center for Fire Research, National Bureau of Standards

A. Spears, Lorillard, A Division of Loews Theatres, Inc.

J. Sharman, Consumer Product Safety Commission

J. Ziolkowski, American Furniture Manufacturers Association

The team's plan was modified slightly and accepted by the Technical study Group.

The test protocol adopted was based on the mini-mockup test arrangement used by the California Bureau of Home Furnishings [8], the Upholstered Furniture Action Committee (UFAC) [9], and the Business and Institutional Furniture Manufacturers Association (BIFMA) [10]. This mini-mockup has generally been used with the cigarette placed only in the crevice and covered with a piece of sheeting. For this project, cigarettes were also to be placed on the flat surfaces and both flat and crevice tests were to be performed with and without the sheeting cover. This arrangement provides for a range of CIR of the substrates for each fabric/padding combination.

The selected ignition criterion was the direct observation of sustained substrate smoldering. This differs from one present practice, the measurement of char length on the fabric surface. Experience in several laboratories [e.g., 11] had shown that obvious ignition and severe smoldering can occur even if the char length on the fabric surface is short. The char length in such cases is thus a misleading measure. In addition, measuring the char length in the padding, especially cotton batting, which has been extinguished by 
immersion in water, exposes the operator to fumes and is both messy and inaccurate.

It was also decided to record the combined weight of the cigarette and substrate versus time during the tests. This permits calculation of the changes in weight loss rate which accompany smoldering ignition of the substrate. The hypothesis was that the weight loss rate before ignition might be an indication of the ignition propensity of the cigarette packings. In addition, flattening of the weight/time curve would be a more reliable indication of self-extinguishment than visual or tactile determination. With the substrates used here, smoldering ignition appeared to occur at a weight loss of about $3 \mathrm{~g}$, but all tests in which ignition occurred were continued to $5.5 \mathrm{~g}$ weight loss. The balances have a capacity of $3000 \mathrm{~g}$ and a resolution of $0.01 \mathrm{~g}$.

Further modifications were made when initial screening tests showed the need for certain minor improvements. The protocol used in the 864 tests is attached as Appendix B.

\subsection{Substrate Material Selection}

The objective of this work was to determine whether there are statist1cally significant differences in the ignition propensities of selected commercial cigarette packings and to identify atypical behaviors. For this purpose, appropriate substrates capable of showing differences had to be identified by screening of commercial materials. However, a substantial part of the soft 
furnishings used in the U. S. (an estimated total of 340 million upholstered furniture items and perhaps three-quarters of the 215 million mattresses [12]) may be expected to resist ignition by all commercial cigarette packings [13]. Another part may be expected to ignite from exposure to all commercial brands. The number of soft furnishing substrates which ignite from contact with some but not other commercial cigarette packings is thought to be relatively small. This is not surprising since the range of physical parameters in the roughly 200 commercial cigarette packings is reported to be quite small [14]. This similarity made the selection of substrates quite difficult.

The Technical Study Group agreed on the use of the "Standard Fabric" used in the California regulatory cigarette test [8]. This and the other materials are described in detail in Appendix B. Another fabric and two paddings, a polyurethane (PU) foam and a cotton batting, were to be selected by CFR after preliminary studies.

Small yardages of middle weight, cellulosic fabrics were purchased locally; however, the fiber contents and weights were unknown, since fabrics in stores generally do not have labels with such information. In addition, two other variables which affect the CIR of fabrics, alkali metal content and type and amount of backcoating, could not be determined in the store.

Samples of several fabrics which were purchased were then tested over a variety of $\mathrm{PU}$ and cotton batting substrates using several cigarette packings which might be expected to differ in ignition propensity. One "dobby weave" fabric/PU combination which demonstrated such differences was chosen. However, 
when the materials were purchased in sufficient quantity to conduct the tests, the differences between cigarettes were no longer found, indicating possible inconsistency with the previously sampled materials. (Only one ignition - of a possible 192 - was found with the chosen dobby weave fabric/PU combination.) Such inconsistent behavior is not unusual for upholstery materials which are generally poorly controlled with respect to fabric weight, backcoating and other finish concentration, and, in some cases, even fiber content of the yarns. Since the dobby fabric did not show the expected cigarette differentiation, a third, more ignitable fabric, called the "tulip" fabric because of its pattern, was also chosen. This fabric performed in the actual testing as it had in screening.

The 100 percent cotton sheeting with which the cigarettes were to be covered (as is prescribed in most soft furnishings CIR tests [8-10]) was also purchased locally, laundered, double rinsed, and tumble dried in home laundering equipment.

Difficulties were also encountered in the selection of cotton batting. For instance, both flame retardant and non-flame retardant rolls of cotton batting were found in what was considered one production lot by the local supplier. Finally, untreated cotton batting was obtained from a manufacturer who only adds flame retardant on special order. Each of the rolls was visually inspected on the premises - small particles of flame retardant added by this manufacturer's process fall out if samples are shaken vigorously. Later, samples from each roll were tested by a colorimetric method by the CPSC 
laboratory and found to contain no borate flame retardant. Borate-based flame retardants are the most common FR agents used for cotton batting.

Similar problems were encountered with the selection of the PU. A foam which ignited with the sample of the dobby fabric and with some but not all cigarette packings was identified. However, as stated above, the combination of the second shipment of this fabric and the selected foam did not ignite. Another foam was chosen on basis of batch to batch consistency and commercial availability.

Smoldering propensity of cellulosic materials is enhanced by the presence of certain metal ions $(15,16)$. To further characterize substrates, the chosen cotton fabrics and batting were submitted to the CPSC laboratory for quantitative determination of $\mathrm{Na}, \mathrm{K}, \mathrm{Ca}$, and $\mathrm{Mg}$ ions. The materials were divided into several parts and samples sent to CPSC from each part, with a duplicate sample from one of the parts. The CPSC report is included as Appendix C. As can be seen, the scatter in the data is within \pm 5 percent. PU samples randomly chosen from the foam shipment were sent for the same analysis to a commercial laboratory; the results are shown in Appendix $D$.

In all, about 70 experiments were needed to complete the materials selection. Those chosen are described in detail in Appendix $B$, as is the manner in which they were sampled for the testing work. 


\subsection{Cigarette Packing Selection}

For this work, the test cigarettes selected were (a) the one used in most present CIR testing work [8-10], (b) several cigarettes which on the basis of previous work might be expected to have different ignition propensities $[3,4,6,7]$, and (c) a number of popular cigarettes. The final selection included ten filter and two non-filter packings. The cigarettes, without identifying marks, were supplied by their manufacturers in coded containers. New codes were assigned and only these were used in further handling. Sampling of the cigarettes used in the tests from the 6,000 to 10,000 cigarettes submitted is described in Appendix B.

\section{RESULTS AND DISCUSSION}

Three types of results were used to compare the cigarette packings: total number of ignitions per packing; the mass loss rate of substrates which ignited; and the mass loss of substrates which did not ignite.

\subsection{Number of Ignitions}

Table 1 lists the number of ignitions by packing and substrate. On each substrate the maximum possible number of ignitions is 48 , that is, all four replicates of 12 packings ignited this substrate. The maximum possible number of ignitions per packing is 4 replicates of 18 substrates or 72 . Tables 2 and 3 summarize these results. 
The relative CIR of the substrates followed patterns found previously in a number of laboratories all over the world, as summarized in a recent literature review [13]. Thus, crevices again had somewhat lower CIR than flat areas and covered flat and crevice substrates had slightly lower CIR than uncovered substrates. As previously found, cotton batting substrates had much lower CIR than PU substrates. (In fact, only certain heavy vinyl, wool, or thermoplastic fiber fabrics would be expected not to ignite over cotton batting when the usual test cigarette is used in a covered crevice. On the other hand, PU would only be expected to ignite under medium weight or heavy cellulosic fabrics. The California Standard Fabric had been chosen by the Bureau of Home Furnishings to eliminate PU with poor CIR from the California market. Apparently, this effort has been quite successful; in the time allotted for the material screening, no PU that would ignite with this fabric was found.)

For the sixteen California and dobby fabric substrates, almost all the variation in number of ignitions among the various cigarette packings occurred in the flat, cotton batting substrates. All other cotton batting substrates resulted in at least 47 ignitions out of a possible 48 . With the same fabrics, essentially no ignitions occurred with the PU substrates. There was, however, some variation among cigarette packings in the two tulip fabric/PU/crevice substrates. (Experiments with all twelve cigarette packings indicated that the tulip fabric would always produce ignitions with cotton batting substrates, and not produce ignitions with flat PU substrates.) The significance of these variations is discussed next. 
A chi square test is appropriate for analysis of single columns in Table 1 in which the average number of ignitions per cigarette packing is between 1.0 and $3.0[17,18]$. Using this test on column 1, California Standard Fabric/cotton batting/flat/uncovered, we determined that the ignition performance of the 12 cigarette packings is different, at a 0.00013 leve 1 of significance. Analysis of the results in column 18, tulip fabric/PU/crevice/covered, shows that the performance differences between cigarettes were not statistically significant, the significance level being 0.30. The remaining columns of Table 1 cannot be tested using the chi square test because the average number of ignitions is not between 1.0 and 3.0 .

The remaining columns can, however, be evaluated for significant differences in the number of ignitions by an exact calculation, analogous to Fisher's Exact Test for a $2 \times 2$ contingency table, based on the conditional probability distribution of the data given the total number of ignitions [19]. Column 2 , CA standard fabric/cotton batting/flat/covered, shows the cigarette packings to be statistically different from each other at the 0.003 level; for column 5 , dobby fabric/cotton batting/flat/uncovered, the significance level is 0.011 . None of the remaining columns approaches statistical significance.

The results show that there are statistically significant differences in the ignition propensity of the chosen commercial cigarette packings (which were not designed by their manufacturers for this purpose) when tested on three of the 18 substrates. However, no one of the packings consistently showed low ignition propensity on all three substrates. Earlier studies found similar differences in ignition propensity of commercial cigarette packings (3-7). 
Some of the earlier studies on commercial cigarettes were performed in the late 1970's; the tar and nicotine delivery of some of the cigarette packings involved has changed, according to the annual FTC reports issued since then [20], indicating changes in their characteristics. However, both the California Bureau of Home Furnishings and the authors believe the differences in ignition propensity to be smaller than in earlier years [21].

There were no differences in the ignition propensities of the cigarettes when tested on the other 15 substrates. The results also suggest that cigarette rankings may depend somewhat on the substrate; much more work would have to be done to prove this point. Modest differences in ignition propensity have also been found with experimental cigarette packings differing systematically in packing density and diameter on some but not all substrates [22].

It should be noted that the 18 selected substrates were not totally independent of each other. For four fabric/padding combinations, tests were conducted in the crevice and in the flat configurations, as well as with and without a cover over the cigarette. A number of laboratories have shown that crevices are considerably more likely to ignite than flat surfaces, and covered cigarettes are somewhat more likely to cause ignition than uncovered ones. (A review of work on relative CIR of substrates is given in [13].) Thus, it is not surprising, for example, to find that when column 12 shows no ignitions, columns 9, 10 and 11 don't either.

The results also indicate that differences in the ignition propensities of these commercial cigarettes can only be demonstrated on a small range of 
substrates. What cannot yet be determined is what percentage of the total population of soft furnishings that might be exposed to burning cigarettes is represented by the borderline substrates, i.e., what percentage of soft furnishings would resist ignition by, e.g., cigarette packing 2 , but not some of the others used in this work.

The results furthermore indicate that, to explore differences in cigarette ignition propensity, it is more effective to investigate a number of fabric/padding combinations than numerous configurations of one fabric/padding combination. For example, a fabric which ignites with PU can be expected to ignite with cotton batting, and fabric/padding combinations which do not ignite in the crevice need not be tried in the flat configuration.

One of the objectives of the commercial cigarette testing was to look for a commonality of properties of relatively low ignition propensity cigarette packings. The data are not "hard" in this area but some observations are presented. The three cigarette packings at the top of Table 1 were of relatively small circumference; however, one other packing with a similar circumference had higher ignition propensity. The two non-filter packings were among the nine more ignition-prone cigarettes. Without thorough analysis of the physical and chemical properties of the cigarette packings - a formidable task not provided for in present plans - no properties could be investigated for their discrete effects on ignition propensity. 


\subsection{Mass Loss Data Obtained During Tests}

Typical mass/time curves, one for a substrate ignition, another for nonignition, are shown in Figure 1. The curves are useful during testing to assist operator judgement whether an ignition has occurred or not. The question also arises whether the shape of the mass loss curve obtained on one or several substrates, or data derived from it, can be used to predict the general ignition propensity of cigarettes. Two mass loss curves have to be considered separately: those for igniting substrates (with considerable inflection of the curve), and those for non-igniting substrates, which indicate total mass loss before self-extinguishment.

\subsubsection{Mass Loss on Igniting Substrates}

In the present substrates, most ignitions occurred at times between the occurrences of 2 and $3 \mathrm{~g}$ mass loss. The slope before ignition could be characterized by the time to $2 \mathrm{~g}$ mass loss. In addition, the times from 4 to 5 $g$ mass loss might characterize the substrate CIR, because at these times, most of the cigarette has burned out and the mass loss is dominated by substrate smoldering. However, this was not part of the present study, and the results are presented here only for the record.

Table 4 shows these results for those cotton batting crevice substrates which ignited with the cigarettes arranged as in Table 1 , i.e., by increasing ignition propensity. As can be seen, the reproducibility in these results is poor; the standard deviations (S.D.) varied from 20 to 30 percent, and in some 
cases, were as large as 60 percent. One could hypothesize that a longer time to $2 \mathrm{~g}$ mass loss on any igniting substrate would be found for those cigarette packings with lower ignition propensity. On a strictly statistical basis, using Pearson correlation and Spearman rank correlation methods, there is no significant correlation between time to $2 \mathrm{~g}$ weight loss and number of ignitions [23]. The time to 4 or $5 \mathrm{~g}$ mass loss was also not predictive of cigarette ignition propensity, and appears to be primarily substrate dependent.

As mentioned before, the dobby fabric had generally lower CIR than the California standard fabric and covered substrates had lower CIR than uncovered ones. However, in the present experiments, the mean time to $2 \mathrm{~g}$ loss was longer for the dobby fabric than the California fabric and longer for the covered than the uncovered substrates. This indicates that some substrates which are more likely to ignite can have longer Ignition times than the less ignition prone ones. A possible explanation is that a heavier fabric may take longer to reach the point of smoldering ignition, but is then more likely to support continuing smoldering.

\subsubsection{Mass Loss on Self-Extinguishing Substrates}

Table 5 shows the mass loss of the fabric/PU substrates which did not ignite. The standard errors for the mass losses for the four replicates of each cigarette packing averaged 11 percent. The averages for each cigarette/substrate combination were normalized by dividing by the tobacco column length measured to the overwrap. (The perforated paper in this sleeve is heavier than the cigarette paper on the tobacco column. The sleeve is used 
to connect the tobacco column and filter.) This length, rather than that of the whole tobacco column, was chosen because the tobacco generally continued smoldering into the overwrap, but did not produce an imprint on the substrate under the overwrap. In other words, the overwrap paper prevented heat transfer to the substrate. (This was confirmed by wrapping cigarettes in overwrap paper. Those cigarettes burned their entire length in air but self-extinguished or made minimum imprints, with no ignition, on a low CIR substrate.)

Again, there was no statistically significant correlation between the number of ignitions on the California fabric/cotton batting substrate and the mass loss of the fabric/PU substrates. For example, cigarette packings 2 and 7 (with low number of ignitions) generally produced low mass loss, but cigarette packing 9, with a higher number of ignitions, also produced relatively low mass 1oss.

\subsection{Effect of Ambient Humidity}

Laboratories in which tobacco products are investigated generally have closely controlled temperature and relative humidity (r.h.) presumably because of the interest in burn rate of cigarettes. No systematic study of $r . h$. effects was included in this study. In our laboratory, the ambient conditions were usually $22 \pm 3^{\circ} \mathrm{C}\left(72 \pm 5^{\circ} \mathrm{F}\right)$ and $55 \pm 108 \mathrm{r} . \mathrm{h}$. However, there were occasional excursions outside those limits, and r.h. ranges of 25-678 occurred at $24^{\circ} \mathrm{C}\left(75^{\circ} \mathrm{F}\right)$. Table 6 shows examples of tests in which the r.h. varied greatly. This variation did not affect occurrence of ignition or non-ignition in these cases. Little or no r.h. effects on cigarette temperature, and in one 
case on heat flux from cigarettes, have been reported in the 1 iterature, but burn rate has been reported to be lower at higher r.h. [24-26].

\section{CONCLUSIONS}

This first project performed under the Cigarette Safety Act of 1984 was intended to determine differences in the propensity to ignite soft furnishings of selected, present-day, commercial cigarette packings. Statistically significant differences among these packings at the 1 percent or higher levels were found for three of the 18 substrates used in this work; no such differences were found on the other 15 substrates. No one of the packings consistently showed low ignition propensity on all three substrates. Other investigators using different substrates, and in many cases different cigarettes, have also found differences in ignition propensity on certain substrates [3-7]. The relationship between the substrates in this study and the existing furniture population has not been determined. Therefore, the impact of the measured differences in cigarette ignition propensities on life safety has not been determined.

The slope of the mass loss curves was helpful in documenting whether ignition did or did not occur. However, two measures derived from these curves, the time to $2 \mathrm{~g}$ mass loss for the igniting cotton batting substrates, and the total mass loss for PU substrates which did not ignite, were not predictive of ignition propensity for all cigarettes tested. 


\section{ACKNOWLEDGMENTS}

Thanks are due to several colleagues: Miss Joan Rotoloni for conducting the experimental work, Mr. Richard Peacock for arranging the data analysis system, Drs. R. and C. Jarvis (Clemson University) and Keith Eberhardt and John Mandel for statistical analysis of the data, to Dr. Stephen Weber for many helpful suggestions, and to Ms. Paula Garrett for word processing the numerous drafts of this report. 


\section{REFERENCES}

[1] Karter, M. J., and Gansarski, J. L., Fire Loss in the United States During 1983, Fire Journa1, 48, Sept. 1984.

[2] Harwood, B., Trend in Cigarette-Ignited Fires, Consumer Product Safety Commission internal memorandum, March 1985.

[3] Damant, G. H., Bureau of Home Furnishings, North Highland, CA, personal communication (1979).

[4] Macaluso, C., Cigarette Ignition Studies, in Testimony, Subcommittee on Health and Environment, House Energy and Commerce Committee (March 21, 1983).

[5] Krasny, J. F., Allen, P., Maldonado, A., Juarez, N., Development of a Candidate Test Method for the Measurement of the Propensity of Cigarettes to Cause Smoldering Ignition of Upholstered Furniture and Mattresses, (NBSIR 81-2363) (U.S.) Nat. Bur. Stand. (1981).

[6] Klancnik, A., Sealy, Inc., presentation to the Technical Study Group, (March 4, 1985).

[7] Ziolkowski, J., Upholstered Furniture Action Committee, Personal Communication, (1985).

[8] Flammability Information Package, State of California, Department of Consumer Affairs, Bureau of Home Furnishings. North Highlands, CA (1983).

[9] Important Consumer Information from UFAC, Upholstered Furniture Action Council, High Point, NC (1984).

[10] The Business and Institutional Furniture Manufacturer's Association First Generation Voluntary Upholstered Furniture Flammability Standard for Business and Institutional Markets, BIFMA, Grand Rapids (1980).

[11] Shaw, A. and Gill, J. T., The Smoldering Behavior of Selected 100 Percent Cotton Fabrics in Combination with Three Different Batting Materials, AATCC International Conference, Chicago, IL (Oct. 1984).

[12] Ray, D., Consumer Product Safety Commission, Personal Communication, $(1986)$.

[13] Babrauskas, V. and Krasny, J.F., Fire Behavior of Upholstered Furniture, Monograph 173, (U.S.) National Bureau of Standards, Gaithersburg, MD (November 1985). 
[14] Spears, A. W., A Technical Analysis of the Problems Relative to Proposed Cigarette Legislation Including a Review of Relevant Patents. Testimony, Subcommittee on Health and the Environment, Committee on Energy and Commerce, U. S. House of Representatives, (Mar. 21, 1983).

[15] McCarter, R. J., Smoldering Combustion of Cotton and Rayon, J. Consumer Product Flammability, 2., 346-358 (Dec. 1977).

[16] Shafizadeh, F., Bradbury, A. G. W., deGroot, W. F., and Aanerud, T. W., Role of Inorganic Additives in the Smoldering Combustion of Cotton Cellulose, Industrial and Engineering Chemistry, Product Research and Development, 21, 97-101 (1982).

[17] Snedecor, G.W. and Cochran, W.G., Statistical Methods, 6th Edition, The Iowa State University Press, Ames, Iowa, 235 (1967).

[18] Lewontin, R.C. and Felsenstein, J., The Robustness of Homogenity Tests in 2 X N Tables, Biometrics, Vol. 21, 19-33 (1965).

[19] Plackett, R.L., The Analysis of Categorical Data, 2nd edition, New York, Macmillan, Section 6.3 (1981).

[20] Federal Trade Commission, Tar, Nicotine and Carbon Monoxide of the Smoke of 207 (number varles with year) Varleties of Domestic Cigarettes, Federal Trade Commission, Washington, DC (1981, 1982, 1983, 1984, 1985).

[21] Damant, G. H., and Williams, S., State of California, Department of Consumer Affairs, Bureau of Home Furnishings, North Highlands, CA, Personal Communications (1985).

[22] Ihrig, A.M., Rhyne, A.L., Norman, V., and Spears, A.W., Factors Involved in the Ignition Propensity of Upholstery Fabrics by Cigarettes, Lorrilard Research Center Report submitted to Technical Study Group (June 1986).

[23] Snedecor, G. W., and Cochran, W.G., Statistical Methods, - 6th Edition, The Iowa State University Press, Ames, Iowa, 194 (1967).

[24] North, M. A., The Relative Fire Hazard of Plain and Tipped Cigarettes, Ministry of Technology and Fire Offices' Committee, Joint Research Organization, Fire Research Note No. 593 (1965).

[25] DeBardeleben, M. Z., Claflin, W. E., and Gannon, W. F., Role of Clgarette Physical Characteristics on Smoke Composition, Recent Adv. Tob. Sci. 4 , 85-111 (1978).

[26] Behnke, W., DuPont deNemours and Co. Cigarette Study - Heat Flux and Ember Temperatures, presented to ASTM Committee D-13 meeting (1969). 


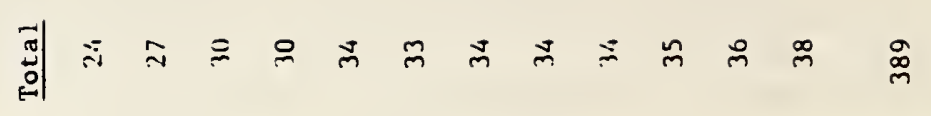

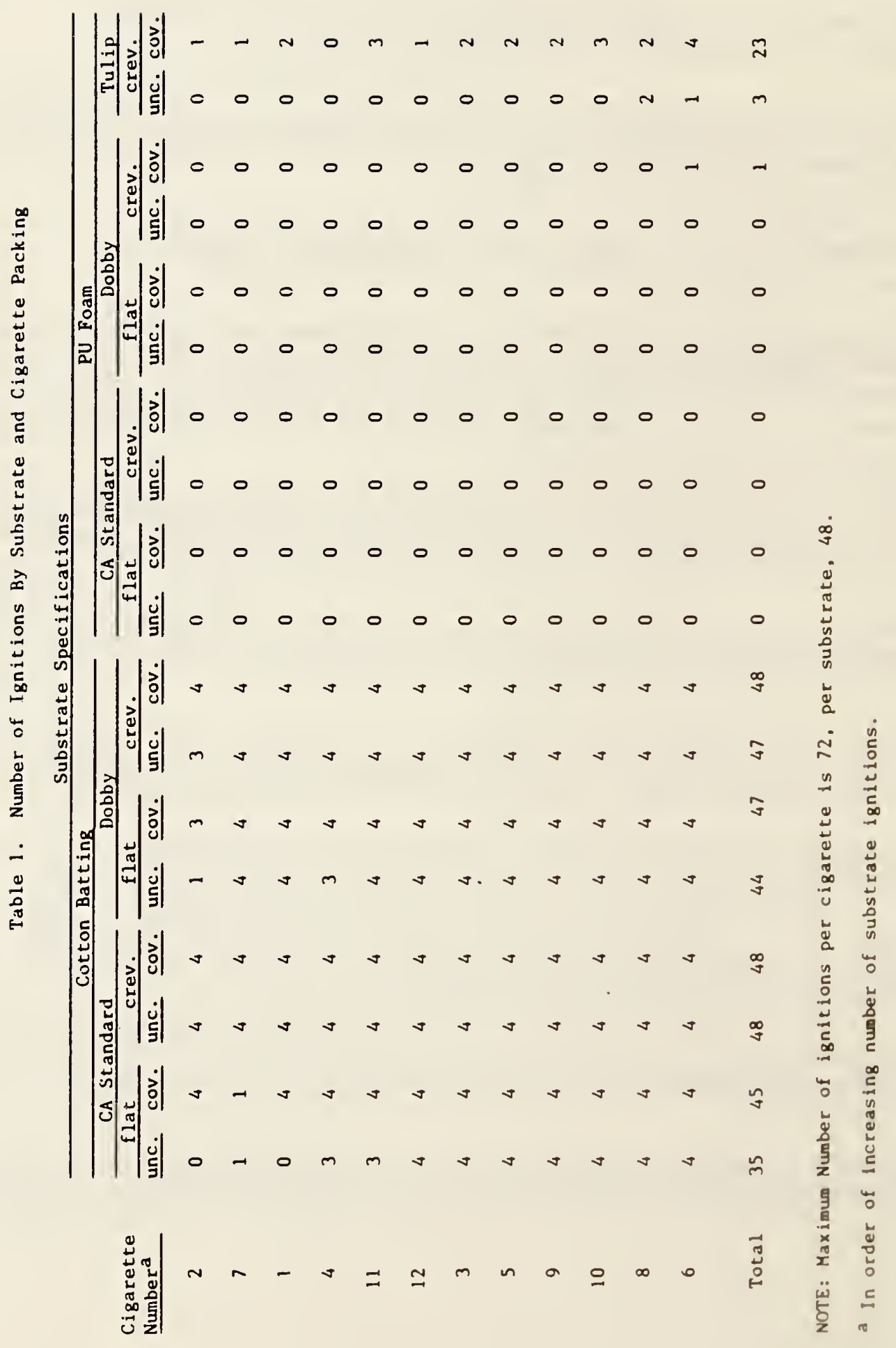


Table 2. Number of Cigarette Ignitions by Substrate Factor (California and dobby fabric substrates only)

No. of Ignitions ${ }^{a}$

Crevice

Flat

CA Fabric

Dobby

Polyurethane Foam

Cotton Batting

Covered

Uncovered
192

171

176

187

1

362

189

174
\& Ignitions

50

45

46

49

0

94

49

45

a The maximum number of ignitions in each case is 384 . 
Table 3. Number of Cigarette Ignition by Substrate Factor (including tulip fabric*)

No. of Ignitions

27

362

176

187

26

215

171

212
177

212
177

(1)

010
No. of Tests

8 Ignitions

Crevice

Flat

Covered

Uncovered

480

384

6

94

384

384

46

Dobby Fabric

Tulip Fabric*

96

49

27

480

45

384

45

432

432

49

41

* Tested over polyurethane/crevice only; probably would have yielded 192 (1008) ignitions over cotton batting 
Table 4. Time to 2, 4, and 5 g Mass Loss of

Igniting Substrates

California Fabric/Cotton Batting

crevice covered

time to mass loss. s

\begin{tabular}{|c|c|c|c|c|c|c|}
\hline & & & \multirow{2}{*}{\multicolumn{2}{|c|}{$4 \mathrm{~g}$}} & \multirow{2}{*}{\multicolumn{2}{|c|}{$5 g$}} \\
\hline \multirow{2}{*}{$\begin{array}{c}\text { Cigarette } \\
\text { No. }\end{array}$} & \multicolumn{2}{|c|}{$2 g$} & & & & \\
\hline & Av. & $\mathrm{SD}$ & Av. & $\mathrm{SD}$ & $\mathrm{Av}$. & SD \\
\hline 2 & 1043 & 564 & 1193 & 657 & 1260 & 669 \\
\hline 7 & 895 & 168 & 1068 & 243 & 1133 & 256 \\
\hline 1 & 768 & 118 & 903 & 146 & 963 & 176 \\
\hline 4 & 718 & 226 & 873 & 307 & 903 & 197 \\
\hline 11 & 740 & 179 & 870 & 252 & 925 & 213 \\
\hline 12 & 958 & 111 & 1120 & 118 & 1190 & 163 \\
\hline 3 & 768 & 125 & 978 & 256 & 1040 & 158 \\
\hline 5 & 738 & 102 & 898 & 127 & 953 & 161 \\
\hline 9 & 745 & 162 & 915 & 243 & 978 & 157 \\
\hline 10 & 853 & 87 & 1010 & 124 & 1065 & 120 \\
\hline 8 & 993 & 277 & 1138 & 383 & 1203 & 114 \\
\hline 6 & 673 & 84 & 810 & 150 & 863 & 142 \\
\hline
\end{tabular}

crevice uncovered

time to mass loss, $s$

$\frac{2 \mathrm{~g}}{\mathrm{Av} . \mathrm{SD}} \frac{4 \mathrm{~g}}{\mathrm{Av} . \mathrm{SD}} \frac{5 \mathrm{~g}}{\mathrm{Av} . \mathrm{SD}}$

$\begin{array}{rrrrrr}875 & 531 & 1018 & 519 & 1085 & 574 \\ 1000 & 210 & 1163 & 327 & 1245 & 185 \\ 830 & 229 & 970 & 230 & 1045 & 277 \\ 680 & 199 & 800 & 218 & 830 & 224 \\ 748 & 128 & 878 & 138 & 948 & 149 \\ 750 & 176 & 885 & 230 & 948 & 89 \\ 693 & 106 & 853 & 137 & 935 & 146 \\ 663 & 120 & 813 & 139 & 850 & 176 \\ 688 & 116 & 853 & 149 & 908 & 188 \\ 698 & 105 & 838 & 103 & 883 & 116 \\ 808 & 140 & 1003 & 167 & 1068 & 208 \\ 685 & 145 & 840 & 199 & 918 & 174\end{array}$

"Dobby" Fabric/Cotton Batting

$$
\text { crevice covered }
$$

time to mass loss, s

Cigarette

No.

$2 \mathrm{~g}$

Av. SD

Av.

(1)

$5 \mathrm{~g}$

$\mathrm{SD}$ Av. SD

$\begin{array}{lll}1210 & 211 & 1510\end{array}$

$\begin{array}{lll}137 & 1595 & 189\end{array}$

$\begin{array}{lll}714 & 1930 & 739\end{array}$

$\begin{array}{lll}379 & 1608 & 336\end{array}$

$\begin{array}{lll}430 & 1388 & 369\end{array}$

$267 \quad 1253$

$469 \quad 1668$

$\begin{array}{ll}169 & 1268\end{array}$

$268 \quad 1193$

$307 \quad 1203$

$211 \quad 1295$

$798 \quad 2035$
2

$281 \quad 1453$ crevice uncovered

time to mass loss, s

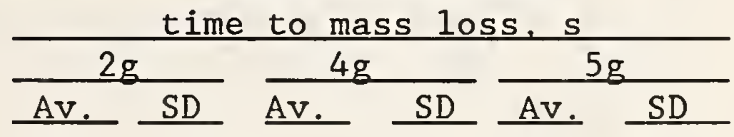

$\begin{array}{rrrrrr}1573 & 331 & 1830 & 432 & 1913 & 398 \\ 1448 & 544 & 1598 & 563 & 1653 & 507 \\ 1065 & 202 & 1233 & 233 & 1298 & 160 \\ 1083 & 249 & 1288 & 298 & 1348 & 332 \\ 845 & 114 & 1015 & 215 & 1070 & 103 \\ 1018 & 168 & 1195 & 308 & 1263 & 209 \\ 838 & 389 & 1030 & 469 & 1100 & 452 \\ 918 & 273 & 1075 & 325 & 1148 & 318 \\ 1083 & 232 & 1238 & 266 & 1318 & 315 \\ 933 & 189 & 1115 & 225 & 1178 & 248 \\ 1020 & 333 & 1203 & 340 & 1275 & 191 \\ 770 & 187 & 953 & 255 & 1020 & 270\end{array}$




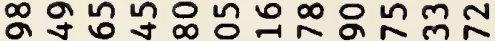
$\dot{\sigma} \dot{0} \dot{0} \dot{\sim} \dot{\infty} \dot{\infty} \dot{\sim} \dot{\infty} \dot{\sim}$

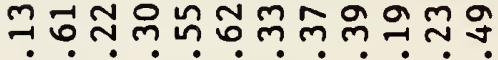

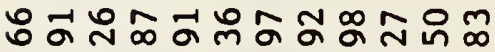
$\dot{-} \dot{\sim} \dot{\sim} \dot{\sim} \dot{\sim} \dot{\sim} \dot{\sim} \dot{\sim} \dot{m}$

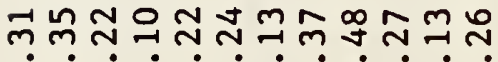

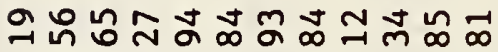
$\dot{-} \dot{-} \dot{-} \dot{-} \dot{-} \dot{-} \dot{-} \dot{i} \dot{\sim} \dot{-}$

ํํำํํㅇㅇㅇㅇํํㅇํำำำำำ

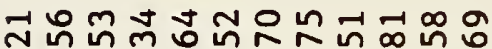
$\therefore \dot{-} \dot{-} \dot{-} \dot{-} \dot{-} \dot{-} \dot{-}$

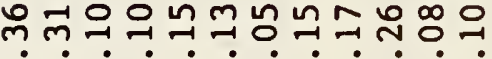

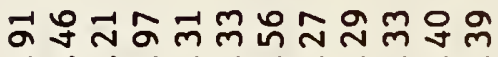
$\dot{0} \dot{-} \dot{-} \dot{0} \dot{-} \dot{-} \dot{-} \dot{-} \dot{-} \dot{-}$
ํํㅇำกำ ตี่ $\dot{y} \dot{0} \dot{0} \dot{0} \dot{\infty} \dot{\sim} \dot{\sim} \dot{0}$

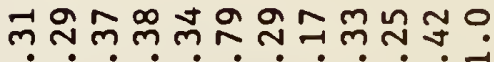

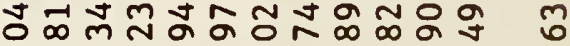
$\dot{-i} \dot{\sim} \dot{i} \dot{i} \dot{i} \dot{\sim} \dot{\sim} \dot{m}$

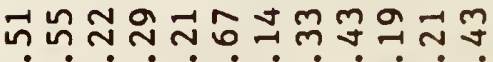

ดัก๊ กิ $\dot{0} \dot{-} \dot{\sim} \dot{\sim} \dot{\sim} \dot{\sim} \dot{\sim} \dot{\sim} \dot{\mathrm{g}}$

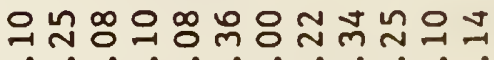

สำษ ำปี่

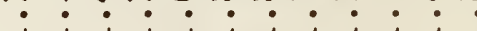
$\stackrel{n}{2}$

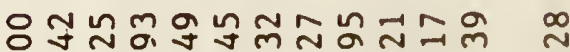
$\dot{-i} \dot{-} \dot{0} \dot{-} \dot{-} \dot{-} \dot{0} \dot{-} \dot{-}$

nกーง

ลำ 
Table 6. Comparison of Typical Individual Ignition Results at Greatly Varying Ambient Conditions

\begin{tabular}{|c|c|c|c|c|c|c|c|}
\hline Cigarette & Fabric & Padding & Config. & Cov/Unc & \multicolumn{2}{|c|}{$\begin{array}{c}\text { Ambient } \\
\text { Cond. }\end{array}$} & $\begin{array}{l}\text { Ignition } \\
\text { Results I/N }\end{array}$ \\
\hline 2 & California & cotton & crevice & $\operatorname{cov}$ & $\begin{array}{l}24^{\circ} \mathrm{C} \\
24^{\circ} \mathrm{C}\end{array}$ & $\begin{array}{l}618 \\
338\end{array}$ & $\begin{array}{l}I \\
I\end{array}$ \\
\hline 2 & California & cotton & flat & unc & $\begin{array}{l}24^{\circ} \mathrm{C} \\
24^{\circ} \mathrm{C}\end{array}$ & $\begin{array}{l}618 \\
338\end{array}$ & $\begin{array}{l}\mathrm{N} \\
\mathrm{N}\end{array}$ \\
\hline 7 & California & $\mathrm{PU}$ & crevice & unc & $\begin{array}{l}24^{\circ} \mathrm{C} \\
24^{\circ} \mathrm{C}\end{array}$ & $\begin{array}{l}638 \\
388\end{array}$ & $\begin{array}{l}\mathrm{N} \\
\mathrm{N}\end{array}$ \\
\hline 1 & California & cotton & crevice & unc & $\begin{array}{l}24^{\circ} \mathrm{C} \\
24^{\circ} \mathrm{C}\end{array}$ & $\begin{array}{l}638 \\
458\end{array}$ & $\begin{array}{l}I \\
I\end{array}$ \\
\hline 11 & California & PU & flat & unc & $\begin{array}{l}24^{\circ} \mathrm{C} \\
24^{\circ} \mathrm{C}\end{array}$ & $\begin{array}{l}638 \\
358\end{array}$ & $\begin{array}{l}\mathrm{N} \\
\mathrm{N}\end{array}$ \\
\hline 11 & Dobby & cotton & crevice & unc & $\begin{array}{l}24^{\circ} \mathrm{C} \\
24^{\circ} \mathrm{C}\end{array}$ & $\begin{array}{l}638 \\
358\end{array}$ & $\begin{array}{l}\text { I } \\
\text { I }\end{array}$ \\
\hline 3 & Tulip & $\mathrm{PU}$ & crevice & $\operatorname{cov}$ & $\begin{array}{l}24^{\circ} \mathrm{C} \\
24^{\circ} \mathrm{C}\end{array}$ & $\begin{array}{l}628 \\
458\end{array}$ & $\begin{array}{l}\mathrm{I} \\
\mathrm{N}\end{array}$ \\
\hline 5 & Dobby & PU & crevice & $\operatorname{cov}$ & $\begin{array}{l}24^{\circ} \mathrm{C} \\
24^{\circ} \mathrm{C}\end{array}$ & $\begin{array}{l}658 \\
388\end{array}$ & $\begin{array}{l}\mathrm{N} \\
\mathrm{N}\end{array}$ \\
\hline 8 & Dobby & PU & flat & cov & $\begin{array}{l}24^{\circ} \mathrm{C} \\
24^{\circ} \mathrm{C}\end{array}$ & $\begin{array}{l}638 \\
528\end{array}$ & $\begin{array}{l}\mathrm{N} \\
\mathrm{N}\end{array}$ \\
\hline 6 & Dobby & cotton & crevice & $\mathrm{cov}$ & $\begin{array}{l}24^{\circ} \mathrm{C} \\
24^{\circ} \mathrm{C}\end{array}$ & $\begin{array}{l}60 \% \\
388\end{array}$ & $\begin{array}{l}I \\
I\end{array}$ \\
\hline 6 & Dobby & cotton & flat & cov & $\begin{array}{l}24^{\circ} \mathrm{C} \\
24^{\circ} \mathrm{C}\end{array}$ & $\begin{array}{l}608 \\
388\end{array}$ & $\begin{array}{l}\mathrm{I} \\
\mathrm{I}\end{array}$ \\
\hline
\end{tabular}




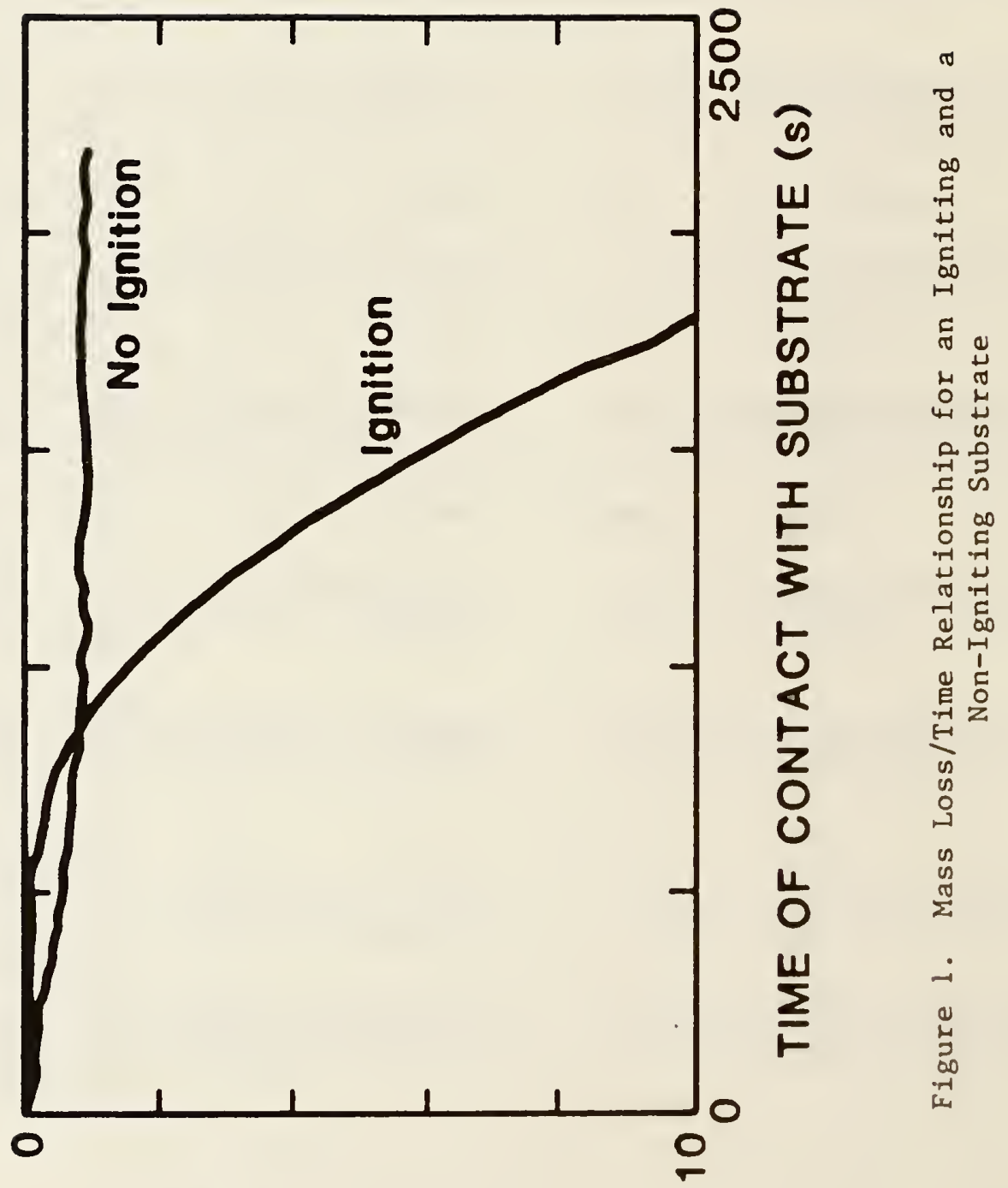

(b) SSOา SS 
Public Law 98-567 98th Congress

\section{An Act}

To etablish an interagency committee and a technical atudy group on cigarette cafety.

Be it enacted by the Senate and House of Representatives of the United States of America in Congress assembled, That this Act may be cited as the "Cigarette Safety Act of 1984".

SEc. 2. (a) There is established the Interagency Committee on Cigarette and Little Cigar Fire Safety (hereinafter in this Act referred to as the "Interagency Committee") which shall consist of-

(1) the Chairman of the Consumer Product Safety Commission, who shall be the Chairman of the Interagency Committee;

(2) the United States Fire Administrator in the Federal Emergency Management Agency, who shall be the Vice Chairman of the Interagency Committee; and

(3) the Assistant Secretary of Health in the Department of Health and Human Services.

(b) The Interagency Committee shall direct, oversee, and review the work of the Technical Study Group on Cigarette and Little Cigar Fire Safety (established under section 3 ) conducted under section 4 and shall make such policy recommendations to the Congress as it deems appropriate. The Interagency Committee may retain and contract with such consultants as it deems necessary to assist the Study Group in carrying out its functions under section 4 . The Interagency Committee may request the head of any Federal depart. ment or agency to detail any of the personnel of the department or agency to assist the Interagency Committee or the Study Group in carrying out its responsibilities. The authority of the Interagency Committee to enter into contracts shall be effective for any fiscal year only to such extent or in such amounts as are provided in advance by appropriation Acts.

(c) For the purpose of carrying out section 4, the Interagency Committee or the Study Group, with the advice and consent of the Interagency Committee, may hold such hearings, sit and act at such times and places, take such testimony, and receive such evidence, as the Interagency Committee or the Study Group considers appropriate.

SEc. 3. (a) There is established the Technical Study Group on Cigarette and Little Cigar Fire Safety (hereinafter in this Act referred to as the "Study Group") which shall consist of-

(1) one scientific or technical representative each from the Consumer Product Safety Commission, the Center for Fire Research of the National Bureau of Standards, the National Cancer Institute, the Federal Trade Commission, and the Federal Emergency Management Agency, the appointment of whom shall be made by the heads of those agencies;

(2) four scientific or technical representatives appointed by the Chairman of the Interagency Committee, by and with the
Oct. 30,1984

[H.R. 1880]

\author{
Cigarette \\ Safety Aet \\ of 1984 . \\ 15 USC 2054 \\ note. \\ Establishment. \\ 15 USC 2054
}

note.

\section{Contrects with}

U.S.

Establishment.

15 USC 2054 note. 
advice and consent of the Interagency Committee, from a list of individuals submitted by the Tobacco Institute;

(3) two scientific or technical representatives appointed by the Chairman of the Interagency Committee, by and with the advice and consent of the Interagency Committee, who are selected from lists of individuals submitted by the following organizations: the American Burn Association, the American Public Health Association, and the American Medical Association;

(4) two scientific or technical representatives appointed by the Chairman of the Interagency Committee, by and with the advice and consent of the Interagency Committee, who are selected from lists of individuals submitted by the following organizations: the National Fire Protection Association, the International Association of Fire Chiefs, the International Association of Fire Fighters, the International Society of Fire Serv. ice Instructors, and the National Volunteer Fire Council; and

(5) one scientific or technical representative appointed by the Chairman of the Interagency Committee, by and with the advice and consent of the Interagency Committee, from lists of individuals submitted by the Business and Institutional Furniture Manufacturers Association and one scientific or technical representative appointed by the Chairman, by and with the advice and consent of the Interagency Committee, from lists of individuals submitted by the American Furniture Manufacturers Association.

(b) The persons appointed to serve on the Study Group may designate, with the advice and consent of the Interagency Committee, from among their number such persons to serve as team leaders, coordinators, or chairpersons as they deem necessary or appropriate to carry out the Study Group's functions under section 4.

Study. 2054 note.

Reports. 15 USC 2054 note.

Termination.
SEC. 4. The Study Group shall undertake, subject to oversight and review by the Interagency Committee, such studies and other activities as it considers necessary and appropriate to determine the technical and commercial feasibility, economic impact, and other consequences of developing cigarettes and little cigars that will have a minimum propensity to ignite upholstered furniture or mat. tresses. Such activities include identification of the different physical characteristics of cigarettes and little cigars which have an impact on the ignition of upholstered furniture and mattresses, an analysis of the feasibility of altering any pertinent characteristics to reduce ignition propensity, and an analysis of the possible costs and benefits, both to the industry and the public, associated with any such product modification.

SEC. 5. The Interagency Committee shall submit one year after the date of enactment of this Act a status report to the Senate and the House of Representatives describing the activities undertaken under section 4 during the preceding year. The Interagency Committee shall submit a final technical report, prepared by the Study Group, to the Senate and the House of Representatives not later than thirty months after the date of enactment of this Act. The Interagency Committee shall provide to the Congress, within sixty days after the submission of the final technical report, any policy recommenda. tions the Interagency Committee deems appropriale. The Interagency Committee and the Study Group shall terminate one month 
after submission of the policy recommendations prescribed by this section.

SEC. 6. (a) Any information provided to the Interagency Committee or to the Study Group under section 4 which is designated as trade secret or confidential information shall be treated as trade secret or confidential information subject to section 552(b)(4) of title 5, United States Code, and section 1905 of title 18, United States Code, and shall not be revealed, except as provided under subsection (b). No member of the Study Group or Interagency Committee, and no person assigned to or consulting with the Study Group, shall disclose any such information to any person who is not a member of, assigned to, or consulting with, the Study Group or Interagency Committee unless the person submitting such information specifically and in writing authorizes such disclosure.

(b) Subsection (a) does not authorize the withholding of any information from any duly authorized subcommittee or committee of the Congress, except that if a subcommittee or committee of the Con: gress requests the Interagency Committee to provide such information, the Chairman of the Interagency Committee shall notify the person who provided the information of such a request in writing.

(c) The Interagency Committee shall, on the vote of a majority of its members, adopt reasonable procedures to protect the confidentiality of trade secret and confidential information, as defined in this section.

SEc. 7. As used in this Act, the terms "cigarettes" and "little cigars" have the meanings given such terms by section 3 of the Federal Cigarette Labeling and Advertising Act.

Confidentiality. 15 USC 2054 note.

Approved October 30, 1984.

LEGISLATIVE HISTORY - H.R. 1880 (S. 1935):

HOUSE REPORT No. 98-917 (Comm. on Energy and Commerce).

SENATE RRPORT No. 98-597 accompanying S. 1935 IComm. on Governmental Afrainst.

CONGRESSIONAL RECORD, Vol. 130 (1984):

Aug 6, considered and passed House.

Sept. 21, considered and passed Senale, amended, in lieu of S. 1935

$\mathrm{Oct}$ 1. House concurred in Senate amendment with an amendment.

Oct 4. Senate concurred in House amendment.

15 USC 2054 note. 

APPENDIX B.

\section{PROTOCOL FOR MEASUREMENT OF THE PROPENSITY OF \\ CIGARETTES TO IGNITE SUBSTRATES}

\section{General}

The Cigarette Safety Act, Public Law 98-567 of October 30, 1984, establishes an Interagency Committee and a Technical Study Group on cigarette safety. The latter group's mandate includes undertaking necessary studies to determine the technical and commercial feasibility of developing cigarettes that have a minimum propensity to ignite upholstered furniture and mattresses. One such study is a survey of the cigarettes currently for sale to determine whether any possess distinguishing ignition propensity.

A protocol to determine the propensity of commercial and experimental cigarettes to ignite various upholstered substrates was written by a task group of the Technical Study Group in July, 1985, i.e., before actual testing started. It was based on test methods presently used by the Business and Institutional Furniture Manufacturers Association (BIFMA), the California Bureau of Home Furnishings, and the Upholstered Furniture Action Council (UFAC). The methods used by these organizations are very similar and are used to determine the relative cigarette ignition resistance (CIR) of furniture substrates using a standard cigarette packing. 
Basically, the proposed protocol consists of placing cigarettes on a number of mockups consisting of an upholstery fabric and padding. The fabric and padding are to be varied to obtain a range of cigarette ignition resistance. However, there is no reason to include extremely cigarette ignition resistant or cigarette ignition prone substrates because they could not be expected to differentiate between present-day commercial cigarettes. Cigarettes are to be ranked by the number of substrates they ignite.

The proposed protocol also provides for a major improvement in defining ignition of substrates by the use of a real-time mass loss-time curves. This obviates the use of surface char length as a criterion of ignition. Ignition is indicated if the curve continues to show mass loss; extinguishment is indicated by a flattening of the curve.

When testing was actually carried out, the need for certain modifications became apparent. Below is a description of the test protocol actually used during the Phase 1 testing of 12 commercial cigarette packings on 16 substrates.

II. Definitions

Cigarette Packing: A commercial cigarette variety, described by its name, length, whether menthol or non-menthol, whether w1th or without filter, and by its package type. 
Crevice: The junction of a horizontal and vertical upholstered furniture surface. For the purpose of this test method, the angle of these two surfaces in the mockup will be as close to $90^{\circ}$ as possible, considering the natural bowing of certain substrates. Other angles may be chosen in follow-up work.

Ignition: Continuous, self-sustaining smoldering or flaming combustion of upholstered substrates which have been exposed to burning cigarettes. Ignition will be determined by operator judgment of "obvious ignition". Later experience has shown that with the Phase 1 fabrics, padding, and cigarettes, obvious ignition occurred at about $3 \mathrm{~g}$ weight loss; tests were consequently discontinued at $5.5 \mathrm{~g}$ or more weight loss.

Substrate: A combination of a cover fabric and a padding material, in either the flat or the crevice area, e.g., the flat area of a piece of polyurethane foam covered with a cotton cover fabric. The crevice made from the same materials was considered another substrate for the purpose of this method, as was the flat specimen without a cover fabric.

III. Safety

Safety precautions consisted of the use of an effective hood, ready availability of breathing apparatus, means of extinguishment of substrates by water spray and immersion in a water bucket, and disposal of the extinguished specimen (after shredding of the charred padding where indicated) in a metal can with well-fitting top. 
IV. General Requirements

Test Apparatus (specimen holder): The specimen holder consisted of two wooden panels, each nominally $203 \times 203 \mathrm{~mm}$ ( 8 × 8 in.) and nominally 19 $\mathrm{mm}$ ( 0.75 in.) thick, joined at a right angles at one edge. Use of rough faced plywood assures that the vertical and horizontal specimens stay in place during the test and obviates the use of the positioning device used in the present UFAC and other test arrangements.

Test Enclosure: To minimize disturbance at the cigarette location during the test, the apparatus was placed into an enclosure, approximately $500 \mathrm{~mm}$ (19.5 in.) square, open on top, and $610 \mathrm{~mm}$ (24 in.) high. The enclosure was placed under a canopy hood. Minimum distance between apparatus and enclosure wall was $76 \mathrm{~mm}$ ( $3 \mathrm{in.}$ ). The front of the enclosure was made from PMMA, to permit observation of the test; the rest was made from plywood. Air velocity at the cigarette location was as low as possible consistent with smoke removal (in a vertical plume as undisturbed as possible) and protection of the operators from fumes during disposal of smoldering specimens.

Balance: Each test apparatus was placed on a balance, with a $3000 \mathrm{~g}$ capacity, $\pm 0.01 \mathrm{~g}$ resolution, capable of taring out test apparatus weight and providing an analog signal output to a data recorder. Visual observation of the time-weight loss slope during the test was helpful in determining ignition. Five balances were used simultaneously. 
Safety Equipment: Breathing apparatus, water spray bottle, immersion bucket, tongs, and metal can with tight top for specimen disposal are required.

V. Test Materials

Fabrics: Two fabrics varying in CIR were used. One was the California Bureau of Home Furnishings Standard Fabric, a $100 \%$ cotton velvet, beige, $340 \mathrm{~g} / \mathrm{m}^{2}$ (10.1 oz $/ \mathrm{yd}^{2}$ ) without backcoating (Pattern 8500, beige, Van Waters and Rogers, 16300 Shoemaker Avenue, Cerritos, CA 90701). The second fabric was purchased locally; its commercial name was "Dijon," the color "pewter". The dealer did not disclose the manufacturer. It was a dobby weave, cotton warp and filling, with a decorative filling stripe approximately $100 \mathrm{~mm}$ wide, $5 \mathrm{~mm}$ distance between stripes. The yarn in this stripe was 1008 polyester, and was located primarily on the backside of the fabric except for small patterns which appeared on the front. The fabric weighed $400 \mathrm{~g} / \mathrm{m}^{2}\left(11.8 \mathrm{oz} / \mathrm{yd}^{2}\right)$. When samples of this fabric were obtained for screening, differences in the ignition propensity of some of the test cigarettes was obtained. However, the screening samples apparently differed from the fabric bolts obtained for this work, which showed no such differentiation.

A third fabric, called the "tulip fabric" because of its pattern, was also acquired locally. It had a rayon background, with a cotton filling 
stripe similar to the above fabric. The weight was $420 \mathrm{~g} / \mathrm{m}^{2}(12.4$ $\left.\mathrm{oz} / \mathrm{yd}^{2}\right)$.

A commercial 1008 cotton sheeting, white, not treated with a flame retardant, $130 \mathrm{~g} / \mathrm{m}^{2}\left(3.8 \mathrm{oz} / \mathrm{yd}^{2}\right)$, laundered once, double rinsed, and tumble dried in standard home laundering equipment, was used to cover the cigarette during the burn.

The alkali metal content of all fabrics will be determined at various places in each roll, to determine uniformity.

Padding: For Phase 1, a foam and a cotton batting padding were used. The foam was a polyether based, polyurethane foam, $34 \mathrm{~kg} / \mathrm{m}^{3}(2.1$ lbs $/ \mathrm{ft}^{3}$ ), $51 \mathrm{~mm}$ thick (2 in.). (HD 2045, Leggett and Platt, High Point, NC. Leggett and Platt only sells in truck loads but the foam is available in small quantities from jobbers, e.g., BCF Supply Co., 2335 W. Franklin Street, Baltimore, MD 21223).

The cotton batting was approximately $40 \mathrm{~kg} / \mathrm{m}^{3}\left(2.5 \mathrm{lbs} / \mathrm{ft}^{3}\right)$, Quality No. 300 from BCF Supply Co., without flame retardant.

The alkali metal content of the batting and foam are were determined by outside laboratories, as shown in Appendices $C$ and $D$. 
Each of the two fabrics was used with each of the two paddings, with and without cover sheet, with cigarettes placed on a flat surface and in the crevice. This resulted in sixteen "substrates".

Cigarettes: In Phase 1, 12 commercial cigarette packings including that which is presently used for testing upholstery CIR, as well as cigarettes reported to have lower propensity to ignite were selected. Cigarettes were assigned code numbers, and packing identities were not revealed.

VI. Size of Test Materials

Cover Fabric: Fabrics for the vertical foam panel were $356 \times 203 \mathrm{~mm}$ (14 $\times 8$ in.) and for the horizontal panel, $203 \times 203$ ( $8 \times 8$ in.). The longer direction was in the warp direction. For the vertical cotton panel, dimensions were $305 \times 305 \mathrm{~mm}$ (12 X 12 in.), for the horizontal panel, $305 \times 254 \mathrm{~mm}$ (12 × 10 in.), with the longer dimension in the filling direction.

Padding: Padding for the vertical panel was $203 \times 203 \times 51 \mathrm{~mm}(8 \times 8 \times$ 2 in.) and for the horizontal panel, $203 \times 127 \times 51 \mathrm{~mm}(8 \times 5 \times 2$ in.).

Sheeting Material: Cotton bedsheeting fabric specimens were $127 \mathrm{x}$ $152 \mathrm{~mm}$ (5 × 6 in.). 
VII. Ambient Conditions: The cover fabrics, paddings, cigarettes, and sheeting were conditioned for at least 24 hours prior to testing as close to $22 \pm 3^{\circ} \mathrm{C}\left(71 \pm 5^{\circ} \mathrm{F}\right)$ and $55 \pm 10 \%$ relative humidity as present equipment permits. Testing proceeded in the same room. The temperature and relative humidity at the time of the test are noted on each test sheet.

VIII. Specimen Mounting

The cover fabrics were mounted with the warp direction perpendicular to the crevice. The cover fabric was in uniform contact with the foam so that no distortion of the foam occurred and the fabric tension was uniform. The fabric was pinned to the back of the foam.

The cover fabric was in as uniform contact with the cotton batting as possible, but due to the tension needed to achieve reasonable contact, some distortion of the cotton batting occurred. The cotton batting was covered on all four edges, and the fabric stapled to an approximately 6 $\mathrm{mm}$ thick ( $1 / 4$ in.) piece of plywood. For the crevice mockups, the horizontal plywood/batting/fabric assembly was placed on a wooden platform, $37 \mathrm{~mm}$ (1.5 in.) thick, so that the cigarette would be above the area of maximum distortion (near the edge) of the vertical assembly. 
IX. Sampling Procedure

The following plan has been worked out with the collaboration of a NBS statistical consultant.

\section{Cigarettes}

From each of the 6000 to 8000 cigarettes per packing, 100 cigarettes were sampled and put in a tray. The 12 trays were appropriately labeled for identification with a new code. The 100 cigarettes were obtained by taking approximately equal numbers from each container in the shipping box. They were randomized in each tray.

In placing the cigarettes on the substrate, care was taken that the cigarette paper seam was not in contact with the substrate.

\section{Fabrics}

The rolls were divided into 4 swatches, in such a way that the entire length of the roll was sampled. Each swatch was cut into a fourth of the total number of specimens required. Then specimens were randomized by hand within each swatch and kept in four separate stacks, labeled $1,2,3$ and 4 . 


\section{Foam}

The foam was cut into the appropriate number of specimens on a band saw, taking the same number of specimens from each sheet. All specimens were thoroughly randomized.

\section{Cotton batting}

Complete randomization of the cotton batting specimens was not feasible because of the difficulty of storing large numbers of specimens. However, in each work period the required cotton batting specimens were taken from the rolls in sequence until each was half depleted. The remaining parts of rolls were stored.

\section{Organization of the Experiment}

The experiment consisted of four "replicate" tests. Each replicate encompassed all 16 test configurations, carried out on all 12 cigarette packings. Replicate \#1 used the fabric stack labeled 1, replicate \#2, the fabric stack labeled 2, etc. To ensure that bias was avoided, the 12 cigarette packings were tested in random order within each replicate and the random order changed from replicate to replicate. 
X. Conducting the Test

A cigarette was lighted and allowed to burn for approximately one minute to stabilize the burn. The cigarette was placed into the crevice so that its center was approximately at the center of the crevice. The cigarette was placed on the flat specimens at an approximately $30^{\circ}$ angle with the warp. The cigarette paper seam was on top of the cigarette. For the "covered" tests, pieces of sheeting were placed over the cigarette; for crevice tests, the sheeting was attached by pins to the vertical panel above the cigarette. A finger run along the length of the cigarette ensured good contact between sheeting and cigarette. The tests were continued until either the weight loss/time curve was flat for several minutes (non-ignition) or at least $5.5 \mathrm{~g}$ weight loss was measured (obvious ignition).

XI. Records

Recorded were: cigarette packing code; cover fabric; padding; crevice or flat area; covered or uncovered cigarette; temperature and humidity in test room; replicate number, balance number, date, and weight at about 20 second intervals.

Char length was not measured because the weight loss/time curve could be made to appear on the screen at any time for any tests and gave a better indication of ignition or non-ignition than an arbitrary surface char length measurement as specified in present test procedures (upward char length only in the UFAC 
tests). Surface char length does not characterize penetration of the smolder into the padding which can differ considerably. However, measuring this depth exposes the operator to the fumes from the charred material, even though it may have been extinguished by wetting. 
TO: Dr. John F. Krasny, Center for Fire Research National Bureau of Standards

THROUGH: Margaret Neily, ES Wh Warren K. Porter, Director, MSHL aNKFnO

FROM:

Kailash C. Gupta, D.V.M., Ph.D., HSHL

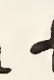

SUEJECT: Analysis for $\mathrm{Na}, \mathrm{K}, \mathrm{Ca}$, and $\mathrm{Mg}$ Content in Fabrics and Cottori-Batting Specimens Provided by Dr. Krasny

The smoldering property of the cellulosic materials has been reported to be affected by the presence of inorganic free radical ions. The factors influencing the smoldering property of cellulosics are of interest to the comission because of their impact on the fires resulting from cigarettes. Samples of four fabrics and one cottor. batting provided by Dr. Krasny, of the National Bureau of Standards, were analyzed for $\mathrm{Na}, \mathrm{K}, \mathrm{Ca}$, and $\mathrm{Mg}$ content. The results are provided in Tables 1 to 5. Analysis of this data along with data from other studies will be conducted by Dr. Krasny.

The analytical procedures used were as follows:

Reference staridard sciutions (1000 ppm) for $\mathrm{Na}, \mathrm{K}, \mathrm{Ca}$, and $\mathrm{MC}$, and the concentrated nitric acid and sulfuric acid were obtained from Fisher Scientific Company. All of the glassware used was washed with $35_{k}$ nitric acid wash. The samples were shredded into smell pieces and each subsample wes analyzed iri replicate. About a gram. of matericl was digested with 10 mil of conceritrated nitric acid and $10 \mathrm{ml}$ of concentrated sulfuric acid by heating for 4 to $\mathrm{c}$ hours until it was completely digested and the solution was clear. upon cooling, the digested solution was diluted with deionized distilled water to the appropriate dilutions. The staridard solutions for each elerient and the reagent blanks were treated the same as the samples ar.e run with each batch of samples, no losses were observed. The e?ements were analyzed with a Perkin Elmer Atoric Absorption Spectrophotometer, Model 503. A standard curve for each element was prepared for each batch of analysis. The elemental content of the materials was calculated using the standard curves, dilution factors, and the weight of material used. Reagent blanks ( $\mathrm{Ma}-0.15 \mathrm{ppr}, \mathrm{K}$ - iess than detection limit, $\mathrm{Ca}-0.2$ ppr. and Mg- 0.02 ppr.) were used for eutomatic zero correction for sample unalyte deternination.

\section{Atzachments}



Appendix C

California Fabric

$\mathrm{Na}$

Sub I

(a)

(b)

Average

Sub IIA

(a)

Average

(b)

Sub III

(a)

(b)

Average

Sub IV

(a)

(b)

Average

565

572

568

559

589

574

576

540

558

578

575

576

572

575

573

570

13

Sub IIb

(a)

Average

OVERALL AVERAGE*

Standard Deviation ${ }^{*}$
Table 1

Sample Number: 593-0158

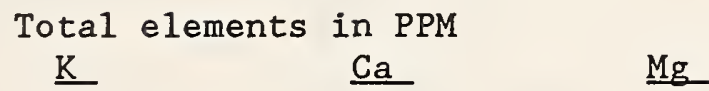

27

235

118

27

27

229

232

119

118

29

28

228

216

222

114

125

119

27

28

27

230

216

223

118

117

117

27

27

27

231

230

230

120

118

119

29

29

228

118

29

220

224

117

117

28

226

118

1

6

3

" Overa11 average and standard deviation calculated at NBS 
Appendix C

Gray dobby

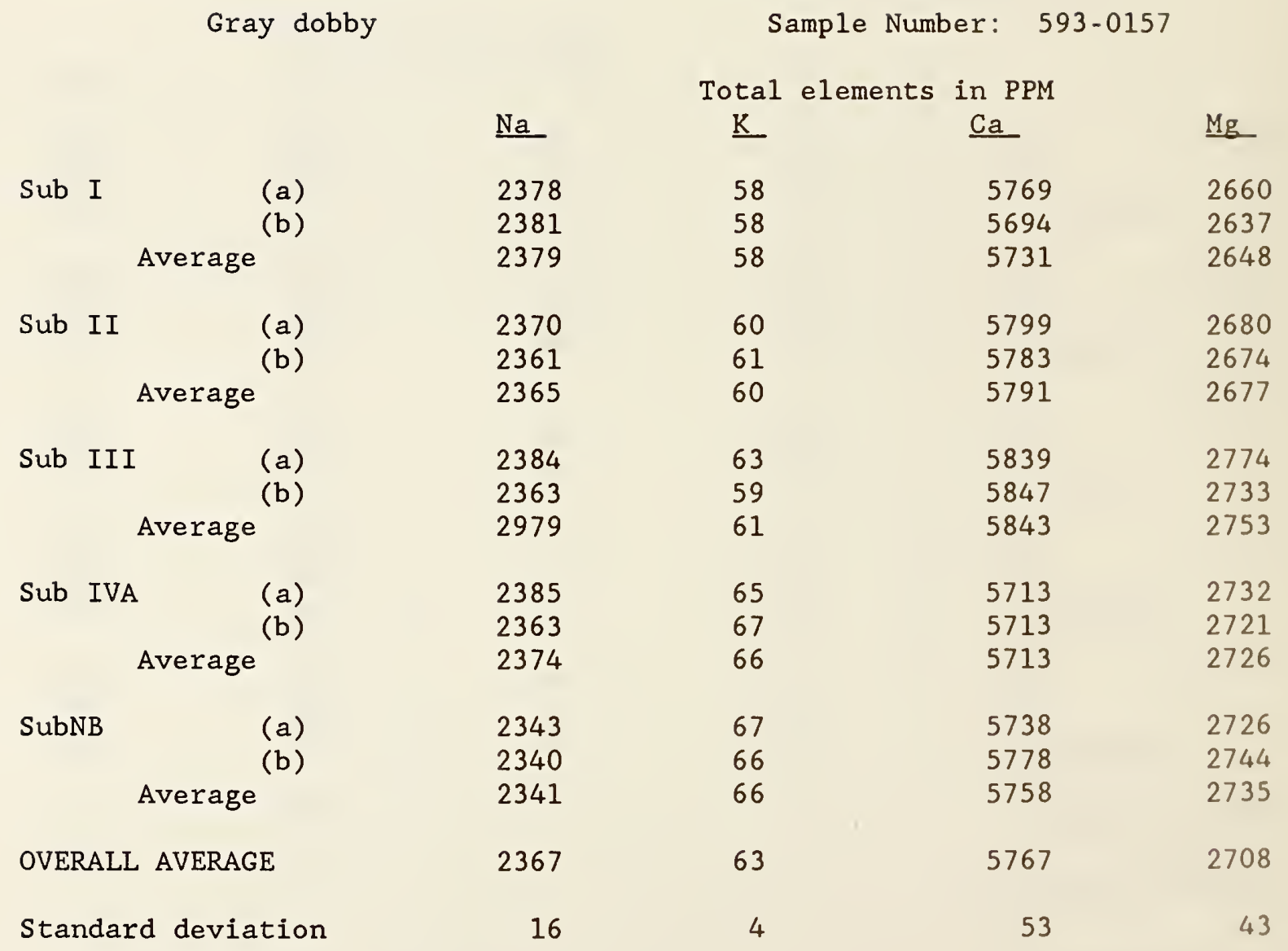

Table 2

able 2 
Appendix C

Tulip Fabric

Sub I

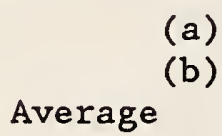

Sub II

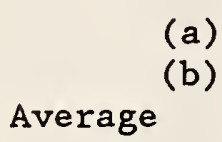

Sub III

(a)

Average

(b)

OVERALL AVERAGE

Standard deviation
Table 3

Sample Number: 593-0159
$\underline{\mathrm{Mg}}$

$\underline{\mathrm{Na}}$

1512

1505

1508

1517

1504

1510

1509

1516

1512

1510

5

\section{Total elements in PPM}

$\underline{\mathrm{K}}$

$\underline{\mathrm{Ca}}$

26

26

26

206

28

28

29

28

28

23

23

23

23

23

23

24

1

6 
Appendix C

Sheeting Material

\begin{tabular}{|c|c|c|c|c|}
\hline & $\underline{\mathrm{Na}}$ & $\begin{array}{c}\text { otal } \\
\underline{\mathrm{K}}\end{array}$ & $\begin{array}{l}\text { in } \mathrm{PPM} \\
\underline{\mathrm{Ca}}\end{array}$ & $\mathrm{Mg}$ \\
\hline Sub I & 364 & 192 & 785 & 2031 \\
\hline (b) & 364 & 192 & 780 & 2021 \\
\hline Average & 364 & 192 & 782 & 2026 \\
\hline Sub II & 371 & 191 & 785 & 2030 \\
\hline (b) & 366 & 187 & 789 & 2020 \\
\hline Average & 368 & 189 & 787 & 2025 \\
\hline OVERALL AVERAGE & 366 & 190 & 785 & 2025 \\
\hline Standard deviation & 3 & 2 & 4 & 6 \\
\hline
\end{tabular}


Appendix C

Cotton batting

$\underline{\mathrm{Na}}$

Sub IA

(a)

(b)

Average

Sub II

(a)

(b)

Average

Sub III

Average $^{(\mathrm{a})}$

Sub IB

(a)

(b)

Average

OVERALI AVERAGE

Standard deviation
Table 5

Sample Number: 593-0161

$\begin{array}{ccc}\begin{array}{c}\text { Total elements } \\ \underline{\mathrm{K}}\end{array} & \begin{array}{c}\text { in PPM } \\ \mathrm{Ca}\end{array} & \underline{\mathrm{Mg}} \\ 192 & 785 & 2031 \\ 192 & 780 & 2021 \\ 192 & 782 & 2026 \\ 194 & & \\ 188 & 787 & 2020 \\ 191 & 788 & 2020 \\ 194 & 787 & 2020 \\ 192 & 785 & 2030 \\ 193 & 794 & 2035 \\ 191 & 789 & 2032 \\ 187 & & \\ 189 & 785 & 2030 \\ 191 & 789 & 2020 \\ 2 & 787 & 2025\end{array}$



P. O. BOX 4187

2323 SYCAMORE DR.
VELMA M. RUSEELL SECRETARY/TREASURER

\title{
PAIIRAIIH
}

\author{
Laforatories, Inc. \\ QUANTITATIVE MICROANALYSES \\ ORGANIC - INORGANIC \\ KNOXVILLE, TENNESSEE 37921
}

PHONE 546-1335

AREA CODE 615

Mr. John Krasny

December 11, 1985

National Bureau of Standards

Building 224, Room A363

Gaithersburg, Maryland 20899

Received: November 11 th

Dear Mr. Krasny:

Analysis of your compounds gave the following results:

Your \#,

Our \#, ppm Ca,

ppm Mg,

ppm Na,

ppm K,

A

M-364 20

1

3

6

9

11

11

B

$M-365$

6

1

12

2

6

3
4

11

C

M-366 8

11

2

10

6

12

Sincerely yours,

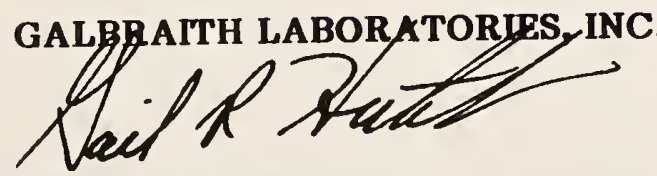

Gail R. Hutchens

Exec. Vice- President

GRH: sc 
U.S. DEPT. OF COMM.

BIBLIOGRAPHIC DATA

SHEET (See instructions)
1. PUBLICATION OR REPORT NO.

NBSIR $86-3421$
2. Performing Organ. Report No. 3. Publication Date

JULY 1986

4. TITLE AND SUBTITLE

\section{RELATIVE PROPENSITY OF SELECTED COMMERCIAL CIGARETTES TO IGNITE SOFT FURNISHINGS MOCKUPS}

5. $A \cup T H O R(S)$

John F. Krasny and Richard G. Gann

6. PERFORMING ORGANIZATION (if joint or other than NBS, see instructions)

7. Contracd Grant No.

NATIONAL BUREAU OF STANDARDS

U.S. DEPARTMENT OF COMMERCE

8. Type of Report \& Period Covered

GAITHERSBURG, MD 20899

9. SPONSORING ORGANIZATION NAME AND COMPLETE ADDRESS (Street, CIty, StOte, ZIP)

Consumer Product Safety Commission

Washington, DC

10. SUPPLEMENTARY NOTES

[Document describes a computer program; SF-185, FIPS Software Summary, is attached.

11. ABSTRACT (A 200-word or iess factual summary of most significant information. If document includes a significant bibliography or iiterature survey. mention it here)

This report covers the first project performed under the Cigarette Safety Act of 1984, the determination of whether and to what extent commercial cigarettes have differing propensities to ignite upholstered furniture substrates. For this purpose, a test protocol was developed under which 12 types of commercial cigarettes were placed on 18 substrates varying in fabric, padding, and configuration. It was found that there are statistically significant differences in ignition propensity among the cigarettes (at the 1 percent or better confidence level) on three substrates. No significant differences were found on the other 15 substrates. However, no one of the packings consistently showed low ignition propensity on all three substrates. The mass loss rate of both the cigarette and substrate during the tests was recorded and did not appear to be a reliable predictor of ignition propensity.

12. KEY WORDS (Six to twelve entries; alphobetical order: capitalize only proper names; and separate key words by semicolons) Cigarettes; fabrics; furniture; furniture padding; Ignition source; smoldering ignition; upholstered furniture.

13. AVAILABILITY

[X] Unimited

For Official Distribution. Do Not Release to NTIS

Order From Superintendent of Documents, U.S. Government Printing Office, Washington, DC 20402.

[X] OPer From National Technical Information Service (NTIS), Springfield, VA
14. NO. OF PRINTED PACES

56

15. Pice

$\$ 9.95$ 

